Syntax Fusion : Jurnal Nasional Indonesia

P-ISSN: $x x x x-x x x x$

E-ISSN : $x x x x-x x x x$

Vol. 1, No. 2, Februari 2021

\title{
OLIGARKI DALAM DEMOKSARI INDONESIA MEMBUAT HUKUM SULIT DI TEGAKKAN
}

\author{
Fitri Kumala, Rahmayuni, Fitri Ariska, Silfira Dinata \\ Universitas Islam Negri Syarif Qasim Riau \\ E-mail: Kumalaftri37@gmail.com, Rahmayuniyuntel@gmail.com, \\ Arrasidah@gmail.com, Dinatasilfira@gmail.com
}

\section{Abstrak}

Secara umum dari perspektif teoritik oligarki tidak sama dengan elit, perbedaannya adalah terletak pada sumber daya kekuasaan yang melandasi nya dan jangkauan kekuasaan. Sumber daya kekuasaannya yang berasal dari jabatan resmi, sedangkan sumberdaya kekuasaan oligarki adalah kekuasaan material.tidak semua elite merupakan oligarki dan juga sebaliknya.

Ada beberapa alasan mengapa kita harus berkomitmen melalui oligarki sehingga tuntas. Oligarki akan menyebabkan nilai-nilai seperti persamaan, parsitipasi politik, keterbukaan, kebebasan, dll. Demokrasi yang terbajak oleh oligarki akan menyebabkan segenap kebijakan semata diserahkan pada pemenuhan kepentingan eksklusif para elit, pengusahaan. Hal ini menyebabkan demokrasi kesejahteraan rakyat menjadi tersendat.

Sementara itu dalam kehidupan bermasyarakat hampir dimana ada mayoritas baik dalam agama, ekonomi, moral, politik, dll. Yang mayoritas sering mengalami penderitaan karena tertekan oleh pihak mayoritas. Dan hubungan antara kaum mayoritas-minoritas sering menimbulkan konflik sosial yang tidak bersahabat.

Hal ini disebabkan adanya perilaku diskriminatif yang muncul karena menganggap klompok lain sebagai out-group yang merupakan lawan bagi mereka terutama bagi kaum minoritas yang di anggap asing oleh kaum mayoritas.

Kata Kunci: Demokrasi, Oligarki, Hukum

\section{Pendahuluan}

Penegakkan nomokrasi atau kegaulatan hukum perlu dijada agar dapat terus berjalan seimbang dengan system demokrasi yang menjadi landasan negara Indonesia. Hal ini penting karena dalam menjalankan demokrasi, Indonesia kerap kali melupakan penegakan kedaulatan hukum yang pada akhirnya berujung kepada berbagai macam praktik penyimpangan dalam pemerintahan demokrasi. Pernyataan tersebut di sampaikan oleh pakar hukum tata negara Mahfud MD . Mahfud menilai kondisi Infdonesia sejak berlangsungnya era refolusi hingga kini telah membuat perkembangan demokrasi 
menjadi ke bablasan. Sankin bebasnya demokrasi ini seringkali jadi melemahkan penegakkan hukum menjadi kekuasaan tertinggi atau nomokrasi. Kekuasaan mempunyai arti prnting bagi hukum karena kekuasaan bukan hanya merupkan instrument pembentukan hukum ( law making ), tapi juga instrument penegakan hukum (law enforcement) dalam kehidupan masyarakat. Pembentukan hukum Khususnya undangundang, dilakukan melmelalui mekanisme kekuasaan politik dalam lembaga legislative dimana kepentingan-kepentingan kelompok masyarakat yang saling bertentangan di upayakan untuk dikompromikann guna menghasilkan satu rumusan kaidah-kaidah hukum yang dapat di terima semua pihak. Hukum juga mempunyai arti penting bagi kekuasaan karena hukum dapat berperan sebagai sarana legalisasi bagi kekuasaan formal lembaga-lembaga negara, unit-unit pemerintahan, dan pejabat negara dan pemerintahan. Legalisasi kekuasaan itu dilakukan melalui aturan-aturan hukum.

Demokrasi yang mengarah ke oligarki kekuasaan barimplikasi pada lemahnya penegakkan hukum. Dan apabila oligarki sudah menguasai demokrasi maka sudah bisa dipastikan, cita-cita terwujudnya pemerataan kekuasaan dan kemakmuran rakyat semangkin jauh. Makin dalamnya jurang antara si kaya dengan si miskin, seharusnya para elit politik membiarkan bahkan menjadi pupuk tumbuh suburnya oligarki. Jangan sampai juga oligarki demokrasi terlindungi dibalik mayoritas dan kekuasaan. Jika ini dibiarkan maka tidak bisa terhindar bandul demokrasi yang begeser kepada oligarki. Oleh sebab itu penulis tertarik membuat tulisan yang berjudul "Demokrsi di Indonesia Membuat Hukum Sulit di Tegakkan”.

\section{Metode Penelitian}

Studi kasus ini mengandalkan analisis dokumen sebagai cara utama dalam menghasilkan argumen di makalah ini. Pertama, Oliogarki dan demokrasi yang membahas tentang perbandingan antara oligarki sekarang dan pada masa orde baru dengan melalui analisis artikel-artikel. Kedua, bahayanya oligarki dalam oligarki, yaitu dimana pemegaang kekuasaan yang mengendalikan oligarki tersebut. Ketiga, minoritas yang menguasai mayoritas. Dan yang ke-empat, pengaruh oligarki dalam demokrasi, dimana membahas tentang dampak-dampak yang yang terjadi apabila oligarki yang menguasai demokrasi.

\section{Hasil dan Pembahasan}

\section{A. Oligarki}

Hasil berbagai survei mengenai politik Indonesia tidak jarang menmyimpulkan bahwa 13 tahun Reformasi tidak membawa perubahan mencolok di Indonesia. Bahkan keadaan pada masa Orde Baru di pandang jauh kebih baik ketimbang keadaan pada masa Reformasi ini. Kadang pemimpin negara di Era Reformasi di pandang kurang tegas, di bandingkan era Soeharto. Ekonomi Indinesia juga secara konsisten juga tumbuh dengan angka cukup tinggi. Pemerataan Ekonomi juga di pandang lebih baik pada era Soerharto. Pandangan itu semua tidak banar, tetapi juga tidak semuanya salah. Benar bahea presiden 
Soeharto jauh lebih tegas. Benar bahwa stabilitas politik dan keamanan jauh lebik terjaga dalam jangka lama di era Soeharto.

Namun, bagaimana dengan nasib orang-orang $t$ ertindas yang tidak dapat menyuarakan pendapat mereka bagaimana pula oligarki kekuasaan pada masa itu lebih tunduk pada diri seorang Soeharto. Soeharto menguasai semua aspek kehidupan masyarakat melalui organisasi-organisasi kemasyarakatan yang dibangun dengan system korporatisme negara yang semua di tunjukkan bagi penumpukan kekuasaan di tangan Soeharto dan para kroninya.

Memang pada masa itu Soeharto menjadi tokoh palung berkuasa dan taka da orang atau kelompok yang memiliki kekuasaan kelompok yang memiliki kekuasaan kelompok atau ekonomi mampu untuk menentang Soeharto. Jaringan intelijen, birokrasi dan politik, dann ekonomu yang bertumpuk pada beberapa orang Soeharto menjadikan negri ini dikuasai para monarch tersebut. Pada masa era Reformasi, orang suka sekali system politik yang demokratis sebagai penyebab dari segala keterpurukan di negri ini. Padahal kita mengetahui betapa oligarki kekuasaan masi membelegu partai-partai politik, sehingga mengganggu partai-partai politik, sehingga menggangggu proses demokrasi, bahkan di dalam partai itu sendiri. Kekuata oligarki tidak tampak pada sendi-sendi kehidupan lain. Jika kita lihat dari sisi penumpukkan kekayaan, era Reformasi, khususnya di era presiden Susilo Bambang Yudhoyono, tampak jeklas betapa mereka yang kaya semakin . namun, mereka yang miskin dan tidak berdaya, semakin banyak pula.

\section{B. Bahayanya Oligarki dalam Demokrasi}

Situasi ini sangan menghawatirkan dan harus ada upaya untuk mencegahnya. Apalagi aroma-aroma "rekonsilasi elit(is)" demikian kuat dan punya potensi tergelincir dalam pusaran elitism yang yang membahayakan. Kebijakan yang di susun secara elitiis diatas subtabsi logika yang tidak popular maupun perubahan yang secara derastis, agenda perjuangan politik yang di sampaikan secara berapi-api menjadi bukti bagaiman mental oligarkis itu ada .

Ada beberapa alasan mengapa kita haarus berkomitmen melawan oligarki hingga tuntas.oligarki akan menyebabkan nilai-nilai seperti persamaan, partisipasi politik, keterbukaan, kebebasan berekspresi, dan terutama kedaulatan rakyat akan tenggelam . situasi ini biasanya akaan berlanjut pada upaya menafikan civil society dan terbelinya institusi-institusi demokrasi. Selain itu oligarki yang di tunjukkan untuk kepentingan yang elitis dan eksklusif akan menyebabkan demokrasi berjalan setengah hati, yakni dari procedural saja, sementara dari sisi subtansi mati. Akibatnya kedaulatan rakya akan menjadi samar dan hanya tampak pada momen konsestasi electoral,

Demokrasi yang terbajak oleh oligarki akan menyebabkan segenap kebijakan semata diarahkan pada pemenuhan kepentingan eksklisif para elite, pengusaha, dan para rekannya. Tidak mengherankan bila kemudian di negara-negara yang demokrasinya setengah matang, kesejahteraan rakyatnya tersendat. Tertelan oleh kartel politik ( Kartz dan Meir 1995 ) yang menyebabkan tumpahan kemakmuran tidak kunjung melimpah. 
Tren oligarki partai politik di Indonesia saat ini tengah kuat dalam mengendalikan pemerintahan. Baik di kalangan eksekutif, legislative, dan yudikatif. Padahal dalam ajaran " Trias Politika" ketiganya memiliki fungsi masing-masing saling control dalam menjaga keseimbangan. Namun, secara empiristik bisa terjadi ketidak seimbangan kekuasaan.salah satu cobtoh konkrit yang baru-baru ini terjadi yaitu pengesahan Perppu Nomor 1 tahun 2020 tentang keuangan negara dan Stabilitas keuangan menjadi undangundang dengan mulus tanpa perdebatan yang berarti di parlemen sebagai indikasi pernyataan di atas. Padahal, Perppu tersebut di gugat ke Mahkama Konstitusi (MK) oleh para tokoh dan para kekuatan elemen masyarakat yang saat ini persidangannya masih berlangsung. Artinya, keputusan tang cepat mengindahkan suara rakyat yang berada di luar parlemen, dengan kata lain bisa di katakana mem-bayoass demokrasi subtansial.

Demikian pula masyarakat yang keritis pada umumnya menduga bahwa gugatan materi pokok Perppu tersebut melalui persidangan yang melelahkan pada akhirnya akan di tolak sebagian atau seluruh hakim MK. Mekanisme ketenegaraan yang formalistik tersebut akan membuktikan kuatnya "Oligarki Partai Politik" dalam memberikan dukungan tanpa reserve terhadap pemerintahan eksekutif, bersama partai koalisinya.

\section{Minoritas Menguasai Mayoritas}

Pemerintahan tentu saja tidak bisa mengabaikan kritik yang di sampaikan PBNU. Bukan hanya kritik itu disampaikan oleh organisasi massa besar dan berpengaruh. Namun karena apa yang di sampaikan oleh PBNU kemarin merupakan persoalan yang juga menggeisahkan banyak orang . para intelektual dan akbtivis sosial di negeri kita bahkan telah melontarkannya sejak lama,

- Minoritas Oligarkis

NU selama ini dikenal kurang dekat denga isu-isu yang bersifat structural seperti ketimpangan, kemiskinan, penguasaan sumber daya ekonomi, atau sejenisnya. Sehingga, masuknya organisasi besar seperti NU ke isu-isu ekonomi politik perlu di beri sambutan hangat. NU pantas diharapkan bisa menjadi “ endorser " penting bagi isu-isu keadilan ekonomi di masa yang akan datang.

Pendekatan ekonomi-politik sendiri sangat bisa digunakan untuk melengkapi dan memperkuat sejumlah isu " tradisional " yang selama ini telah mereka geluti. Terkait isu toleransi, misalnya, keadilan sosial adalah kata kunci yang tak bisa di abaikan, sebab, meminjam sebuah riset SMERU (2017), ada hubungan positif antara kemiskinan dan ketimpangan dengan konflik. Hasil kajian SMERU sama dengan hasil sutvei yang dilakukan oleh Wahid Fundation (2017) yang mencatat salah satu factor utama penyebab intoleresi adalah perasaan keterpinggirkan dsdan terampas dari kehidupan sosial, politik, atau ekonomi. Makannya, tepat sekali saat K.H Said Aqil Siroj menyebut juka penguasa segelintir orang tasa proyek-proyek pembangunan pemerintahan disebutnya sebagai bentuk " intoleransi ekonomi" . istilah "intoleransi ekonomi" sendiri adalah neologisme yang sangat berharga termiologi ini bisa memberi sudut pandang baru atas sejumlah isu tradisional, terutama yang berhubungan dengan soal "mayoritas" dan " minoritas ". Jika semala ini isu " toleransi " per se indetik sebagai perangkat advokasi bagi kelompom 
minoritas, misalnya, sehingga kebelakangan memunculkan kesan jika seluruh kelompok yang statistic minoritas pastilah butuh untuk di bela, belakangan termasuk kelompok LGBT; maka terminology " intoleransi ekonomi "bida mengubah kesan tadi. Dalam konteks ekonomi, justru minoritas oligarkilah yang harus di gugat, dan bukannya di bela.

Barangkat dari sudut pandang tadi, mayoritas dan minoritas secara konseptual sebenarnya memang tak otomatis mewakili hubungan biner antara " pendominasi" dan " terdominasi “ . mayoritas dan minoritas adalah suatu hal, sementara pola relasi kuasa diantara keduanya adalah hal lain. Artinya, posisi sebagai mayoritas tak selalu menggambarkan kekuasan sebagai pemdominasi. Bisa jadi untuk konteks tertentu, mayoritas justru menjadi pihak yang terdominasi. Kritik NU terhadap oligarki yang menguasai pemerintahan, misalnya, adalah kritik untuk kelompok minoritas. Kritik terhadap kelompok minoritas oligarkis tersebut sepenuhnya valid. Meski pemerintahan berulang ,menyatakan keberpihakannya kepada usaha mikro, kecil, dan menengah (UMKM), misalnya serta mendororng agar terjadi peningkatan kredit UMKM dari perbankan, namun fakta dilapangan jauh dari klaim tersebut, merujuk pada bank Indonesia, jumlah kredit UMKM memang terus meningkat dari tahun ke tahun. Namun, lajunya sangat lambat jika di bandingkan dengan kredit bagi non-UMKM. Bahkan, porsi kredit bagu UMKM selama priode pertama pemerintahan presiden jokowidodo tidak pernah berhasil melampaui angka pada tahun 2014 .

Setelah mengkritik minoritas oligarkis, kita berharap NU memberikan pembelaan pada pelaku ekonomi rakyat yang jumlahnya mayoritas tadi. Apalagi, menghadapi ancaman resesi global, peran UMKM memang seharusnya kian diprioritaskan oleh pemerinah. Sebagaimana telah terbukti pasa krisis 1997/1998. UMKM adalah sector liat (resillence) yang tahan banting dan sanggup menghadapi krisis.

Setidaknya ada tiga keunggulan UMKM jika dibandingkan pelaku ekonomi besar. Pertama, UMKM pada umumnya menghasilkan barang dan jasa yang menjadi dasar kebutuhan masyarakat. Sehingga, sector ini tidak akan pernah kehabisan permintaan. Kedua, UMKM memproduksi barang dan jasa dengan mengendalikan bahan baku local, sehingga derajat ketergantungannya terhadap global ekonomi kecil. Ketiga, UMKM pada umumnya menggunakan modal sendiri, tidak terkait ada permasalahan perbankan. Meski di suatu sisi hal ini membuat mereka menjadi sulittumbuh besar, namun, disisi lain ini membuat mereka jadi tak mudah terimbas krisis. Pola interaksi yang berbeda dengan perekonomian global ini pula yang menjelaskan mengapa krisis memukul lebih keraas para pelaku besar di bandingkan UMKM.

Mengingat posisinya yang mayoritas, namun minor dalam dalam hal fasilitas, kita bisamenyebut para pelaku ekonomi rakyat ini sebagai golongan " mayoritas mustasdh'afin “ . kita tahu, Al-quran juga menggunakan tema mustad'afin untuk menjelaskan kaum yang lemah atau terpinggirkan ( marginal society ) yang butuh di bela. Dalam diskusi klompok politik, konsep mustad'afin ini bisa digunakan sebagai seruan moral untuk membela kaum yang lemah secara structural. Dan kaum yang lemah itu tak lain adalah para pelaku ekonomi rakyat yang jumlahnya mayoritas di negri ini. 
Bagi kalangan Islam, konsep mustad'afin sebenarnya bisa mengingatkan bahwa di luar wacana marxisme, agama sebenarnya juga menyediakan prangkat analisis untuk mengatasi problem-problem structural yang berkembang di tengah masyarakat, termasuk soal ketimpangan dan ketidak adilan ekonomi. Apalagi, sejarah para nabi dan rosul hampir semuanya berisi perjuangan untuk membela kaum tertindas dan terpinggirkan. Jika ormas-ormas mau masuk ke wilayah kritik ekonomi- politik, ini akan jadi dorongan bagus agar bisa lahir kebijakan afirmatif (affirmative action) yang lebih serius dan matang bagi para pelaku ekonomi rakyat. Sudah saat nya memang para pemimpin keagamaan membela para golongan “ mayoritas mustad'afin “. Dan pembelaan itu bida di mulai dengan membongkar mayoritas-oligarkis yang saat ini diprepsentasikan oleh kongsi para elite partai dengan para taipan.

\section{Pengaruh Oligarki dalam Demokrasi}

Dalam system demokrasi modern, secara teori, partai politik bersifat inklusif, terbuka untuk semua warga negara. Masing-masing orang mempunyai kesempatan yang samaa untuk bersaing masuk dan urun rembuk kedalam struktur partai. Namun, di Indonsia, pada kenyataannyaa partai politik yang ada rentan di sandera oleh berbagai kepentingan kelompok sehingga sifatnya berubah menjadi amat eksklusif, bahkan, cendrung feudal kerena di wariskan secara turun-temurun melalui patronasi kekeluargaan maupun kolega. Para partai yang terkesan lambat baradaptasi dengan system baru di Indonesia yang dihembuskan dengan semangat reformasi pada dua decade yang lalu.

- Kelompok oligarki,

Salah satu penyebab lemahnya proses demokratisasi melalui partai adalah adanya cangkeraman yang kuat pada system partai oleh sekelompok orang. Orang-orang ini menggunakan kekuatan material untuk mendominasi struktur partai, mengendalikan arah politik, dan menghalangi setiap upaya perbaikaan sejak dari akar rumput. Dalam buku Rebublik plato menamai sekelompok orang ini denga sebutan oligarki, yaitu bentuk pemerintahan yang dilakukan oleh " orang-orang serakah " yang sangat mencintai uang sehingga " mereka engan membayar apajak " untuk kebaikan bersama.

Meskipun dalam bahasa yunani oligarki secara harfiah berartu pemerinahan oleh segelintir orang. Plato menggantikannya denga sedikit orang kaya untuk membedakan oligarki dari timokrasi. Jeffrey Winters dalam bukunya " Oligarchy " menyebut oligarki, sebagai kelompok minoritas berbasis materi yang mengarahkan kekuatan materinya secara politis untu memertahankan kekayaannya dari berbagai ancaman sepeti negara, oligarki lain, masyarakat, atau kombinasi ketiganya. Ketika menghalau ancaman yang datang, para oligarki menempuhnya dengan beragam cara, dari menggunakan kekuatan peribadi, instrument koersif, supremasi hukum sehingga kesepakatan bersama untuk mempertahankan kekayaan mereka. Winters berpendapat bahwa ada empat jenis oligarki, yang masing-masing berupaya menjaga kekayaan ny melalui sara yang berbeda. Oligarki ini di kategorikan berdasarkan sifat ( pribadi atau koleksif) dan bentuk pendekatan ( paksaan atau kompromi ) empat jenis oligarki tersebut adalah (1) oligarki yang berperang, seperti jendral perang. Mereka adalah oligarki yang memiliki misi yang bersenjata (2) 
oligarki mafia, yang bersifat kolektif juga bersenjata. (3) oligarki berbentuk sultanistik yang bergerak melalui system koneksi peribadi. (4) oligarki dalam pemerintahan yang bersifat kolektif dan di jalan kan melalui supermasi hukum.di Indinesia, kelompok oligarki memiliki sejarah panjang dan hidup berkelindang dengan perubahan gerakan politik dari waktu ke waktu. Meski terus berganti rupa, namun, wataknya selalu sama. Reorganisasi adalah kunci bagi oligarki bertahan dari setiap perubahan.

- Menemukan diri kembali

Pasca Reformasi oligarki yang di pelihara Orde Baru menemukan kembali dirinya dengan menjajah institusi demokrasi Indonesia melalui partai dan parlemen. Mereka akhirnya dapat kembali eksis berkat disorganisasi masyarakat sipil yang endemic dan sistematis yang di topang oleh puluhan tahun pemerintahan otoriter yang kaku dan sering kali beruntal. Konsekuensinya jelas, kekuatan sosial yang secara efektif mewakili bentuk alternative politik liberal atau sosial democrat hampir tidak terlihat setelah jatuhnya Soeharto. Hingga hari ini, yang kiri tentu akan selalu di benci serentak akan di lenyapkan secara resepsif.

Secara garis besar, Robbison dan Hadiz, salah satu upaya bertahan hidup, jaringan oligarki memanfaatkan ruang yang di sediakan para proses desentralisasi. Dengan dukungan kekayaan material yang berlimpah, jaringan oligarki lama ini berusaha tetap menjadi kekuatan dominan di tingkat lokal. Hal itu dilakukan dengan menguasai partai politik, memainkan politik uang dan suap, serta mengerahkan aparat kekerasan nonNegara untuk menghalau segala macam ancaman. Dengan demikian, elemen-elemen oligarki tetap hidup dengan bentuk jaringan patronase baru yang bersifat desentralistik, lebih cair, dan saling bersaing satu sama lain dengan memanfaatkan berbagai perubahan institusi.

Selain itu, menurut Crouch, oligarki dewasa ini berevolusi melalui pengambil alihan perang masyarakat sipil-terutama kelas menengah yang memiliki kepedulian daan kesadaran politik untuk membangun tatanan politik yang berkeadilan, berkemanusiaan, dan sederajat (equal). Namun, berbeda dengan karakter kelas menengah penggerak demokrasi, oligarki lebih berorirntasi pada pendekatan populisme untuk menopang kekuasaan yang lebih eksklusif, terutama dalam hal formulasi dan implementasi kebijakan pemerintah. Mereka berusaha menciptakan wacana politik baru berikut " opsiopsi solusi praktis "sebagai sikap politik-politik yang di klaim sebagai " kepentingan umum " atas berbagai persoalan yang di hadapi masyarakat.

Slogan populisme yang di munculkan, alih-alih digunakan sebagai kekuatan antagonis terhadap oligarki, justru gagal menjadi kekuatan perlawanan alternatif terhadap praktik-praktik demokrasi Indonesia yang telah di kooptasi secara sistemik oleh oligarki predator. Agenda populis semata-mata digunakan untuk merealisasikan kepentingan pribadi untuk mengamankan sumber daya ekonominya, sehingga dapat di pastikan berbagai jargon politik yang di kumandangkan orang-orang ini hanya bersigat superfisial, karena telah di kacaukan oleh agenda pribadi. Dalam kondisi seperti ini, nuansa dan atmosfir oligarki menghantui dinamika kehidupan politik riil.

- keterlibatan dalam politik 
Keterlibatan oligarki dalam politik sudah hampir pasti dilatarbelakangi oleh upaya untuk menjaga kekayaan pribadi-apa yang di sebut Winters sebagai “ Industri Pertahanan Kekayaan " politik menjadi kanal potensial untuk menjalankan kekuasaan demi menjaga kekayaannya. Mereka dapat bebas memilih untuk mendukung, mensponsori, atau bahkan menjadi elit politik. Penetrasi yang berujung pada kenaikan dan pengaruh oligarki kedalam partai politik Indonesia dapat di telusuri sejak pemilihan umum ( pemilu ) langsumg di lakukan pada tahun 2004. Pada saat itu, secara sifnigfan pemilu mulai menelan banyak untuk kampanye, konsultan, survey elektabiltas, dan iklan media. Diperkirakan biaya kampanye presiden meningkat 10 kali lebih banyak dengan adanya penerapan system pemilihan langsung. Pemilu yang menekan banyak biaya, memungkinkan oligarki masuk melalui system pendanaan kampanye, ruang ini selanjutnya di eksplotasi untuk menekan pimpinan partai melalui upaya mempengaruhi keputusan politik partai yang bisa menguntungkan diri sendiri.

Ancaman kekuasaan oligarki di Indonesia sangat nyata, dan itu dapat dilihat melalui ketimpangan ekonomi antara orang kaya dan orang miskin. Kesenjangan kekuasaan material dalam masyarakat Indonesia merupakan salah satu yang terbesar di dunia. Menurut Arif Budimanta, kekayaan nasional Indonesiai masih di kuasai segelintir orang. $10 \%$ orang terkaya di Indonesia menguasai $74,8 \%$ kekayaan nasional, dalam pertumbuhan 10 tahun sebesar $317,1 \%$ atau 4 kali dibandingkan pertumbuhan nasional. Dalam perkembangan dekade pasca reformasi, kelompok oligarki mengalami pasanga surut keterkaitan. Namun, mereka tidak pernah secara serius untuk berpisah. Semangkin mudah mereka saling meninggalkan, semangkin muda pula mereka membentuk koalisi. Kasus friksi dalam sejarah panjang partai Golkar menggambarkan bagaiman perseteruan antara oligarki di satu waktu, tetapi dapat mesra di waktu yang lain. Mereka bisa memisahkan diri membentuk membentuk partai baru di satu sisi, pada sisi yang lain mereka bisa bersatu untuk memberikan dukungan politik. Keberatan oligarki didalam pilpres telaah memulai kritik yang luas. Dikawatirkan akan ada pemberitaan yang tidak berimbang soal Pilpres dan pada akhirnya menawan agenda kerja dari presiden di kemudian hari.

Oligarki media memainkan peran penting dalam pembingkaian dan hasil pemilihan presien. Kasus deklarasi kemenangan Prabowo yang di siarkan di TV Onesecara berulang pada 2014 yang lalu menunjukkan hal iti, ini berlanjut selama kampanye pemilihan presiden 2014 ketika media arus utama semacam Metro TV berkontribusi terhadap kesuksesan Joko Widodo secara keseluruhan. Pada akhirnya berbagai pemberitaan dikanal arus utamanya, tetap menjadi cerminan paersaingan kaum oligarki media. Alih-alih mencerminkan kepentingan public, keberagaman pemberitaan di media adalah wajah dari berbagai kepentimgan actor oligarki pemiliknya. Pengalaman dari banyak negara menunjukan, ketika oligarki media menguat, para pemili media masuk ke gelangang politik dengan menggunakan medianya sebagai senjata utama untuk menggiring opini publik. Para pemilik media masuk ke gelenggang politik tidak sekedar dalam kerangka politik electoral. Ada kepentingan bisnis juga di sana. Masuk ke gelenggang politik memungkinkan para pemilik media selangkah lebih maju dalam 
mempengaruhi regulasi agar menguntungkan bisnis di media. Sulitnya merevisi di undang-uandang penyiaran ( yang sudah di ajukan sejak 2009 ) menjadi salah satu contoh paling gambling dari hal tersebut.

\section{Penutup}

Oligarki adalah bentuk pemerintahan yang ke kuasaan politiknya secara efektif di pegang oleh kelompok kecil dari masyarakat nya, baik di bedakan menurut ke kayaan keluarga, atau militer. Ancamaan kekuasaan oligarki di Indonesia sangat nyata, dan itu dapat dilihat melalui ketimpangan ekonomi antara orang kaya dan orang miskin, yang pendekatan ekonomi-politik sendiri sangat bisa digunakan untuk melengkapi dan memperkuat sejumlah isu " tradisional " yang selama ini telah mereka geluti. Terkait isu toleransi, misalnya, keadilan sosial adalah kata kunci yang tidak bisa diabaikan penyebab melemahnya proses demokrasi melalui partai politik adalah adanya cengkraman yang kuat pada system partai pada sekelompok orang. Dan kita haarus waspada terhadap untuk menghadapinya semoga di negara kita yang sekarang ini oligarki bisa merata untuk semua kalangan manusia tanpa ada perbedaan antara yang kaya dan yang miskin.

\section{Bibliografi}

Dipo Alam. Deputi Menko Perekonomiaan (2000-2006), alumni George Washington Univesity.

Andrain, Charles F. (1992). Kehidupan Politik dan Perubahan Sosial. Yogyakarta: Tiara Wacana.

Denzin, Norman K and Yvonna S. Lincoln. (2009). Handbook of Qualitative Research. ( Terjemah oleh Dariyanto, Badrus Samsul Fata, Abi, John Rinaldi) Yogyakarta: Pustaka Pelajar.

Winters, Jeffey A. (2011). Oligarki. Jakarta: Gramedia Pustaka Tama.

Winters, Jeffrey A. (2013). Oligarki dan Demokrasi di Indonesia. Dalam Majalah Prisma.

https://m.mediaindonesia.Com/politik-danhukum/148526/demokrasi-indonesia-dibawah-kendali-oligarki. 